\title{
Increased Cellular Uptake of Biocompatible Superparamagnetic Iron Oxide Nanoparticles into Malignant Cells by an External Magnetic Field
}

\author{
Sara Prijic · Janez Scancar • Rok Romih • \\ Maja Cemazar • Vladimir B. Bregar • \\ Andrej Znidarsic · Gregor Sersa
}

Received: 22 December 2009/ Accepted: 11 June 2010/Published online: 3 July 2010

(C) The Author(s) 2010. This article is published with open access at Springerlink.com

\begin{abstract}
Superparamagnetic iron oxide nanoparticles (SPIONs) are used as delivery systems for different therapeutics including nucleic acids for magnetofectionmediated gene therapy. The aim of our study was to evaluate physicochemical properties, biocompatibility, cellular uptake and trafficking pathways of the custom-synthesized SPIONs for their potential use in magnetofection. Customsynthesized SPIONs were tested for size, shape, crystalline composition and magnetic behavior using a transmission electron microscope, X-ray diffractometer and magnetometer. SPIONs were dispersed in different aqueous media to obtain ferrofluids, which were tested for $\mathrm{pH}$ and stability using a $\mathrm{pH}$ meter and zetameter. Cytotoxicity was determined using the MTS and clonogenic assays. Cellular uptake and trafficking pathways were qualitatively evaluated by transmission electron microscopy and quantitatively by inductively coupled plasma atomic emission spectrometry. SPIONs were composed of an iron oxide core with a diameter of 8-9 nm, coated with a 2-nm-thick layer of silica. SPIONs, dispersed in $0.9 \% \mathrm{NaCl}$ solution, resulted in a
\end{abstract}

\footnotetext{
S. Prijic · V. B. Bregar · A. Znidarsic

Kolektor Group, Nanotesla Institute, Stegne 29, 1521 Ljubljana,

Slovenia

e-mail: sara.prijic@nanotesla.si

J. Scancar

Institute Jozef Stefan, Jamova 39, 1000 Ljubljana, Slovenia

R. Romih

Faculty of Medicine, Institute of Cell Biology, University of

Ljubljana, Lipiceva 2, 1000 Ljubljana, Slovenia

M. Cemazar · G. Sersa $(\bowtie)$

Department of Experimental Oncology, Institute of Oncology

Ljubljana, Zaloska cesta 2, 1000 Ljubljana, Slovenia

e-mail: gsersa@onko-i.si
}

stable ferrofluid at physiological $\mathrm{pH}$ for several months. SPIONs were not cytotoxic in a broad range of concentrations and were readily internalized into different cells by endocytosis. Exposure to neodymium-iron-boron magnets significantly increased the cellular uptake of SPIONs, predominantly into malignant cells. The prepared SPIONs displayed adequate physicochemical and biomedical properties for potential use in magnetofection. Their cellular uptake was dependent on the cell type, and their accumulation within the cells was dependent on the duration of exposure to an external magnetic field.

Keywords Superparamagnetic nanoparticles . Endocytosis - Magnetic field · Malignant cells . Internalization

\section{Introduction}

Recent advances in engineering particles a few nanometers in diameter have opened new possibilities for targeting cells within an organism for either diagnostic or therapeutic purposes. A particle of any kind of material which has one or more dimensions equal to or smaller than $1,000 \mathrm{~nm}$ is called a "nanoparticle" (Kreuter 1994). Due to their size, nanoparticles can overcome various physiological barriers as well as penetrate into and/or through cells (Willard et al. 2004). Nanoparticles consisting of elements such as iron, nickel and cobalt and exhibiting magnetic properties are called "magnetic nanoparticles." Due to their magnetic properties, magnetic nanoparticles can be manipulated by an external magnetic field. Magnetic nanoparticles which are small enough, composed of iron oxide and display magnetic behavior only in the presence of an external magnetic field are called "superparamagnetic iron oxide 
nanoparticles" (SPIONs). Magnetic nanoparticles and SPIONs are used in different biomedical applications, such as contrast agents in magnetic resonance (MR) imaging, tissue repair, immunoassay, detoxification of biological fluids, anticancer magnetic hyperthermia, cell separation as well as delivery systems (Gupta and Gupta 2005; Mirkovic et al. 2010).

SPIONs as delivery systems for therapeutic approaches can act as vehicles for many different molecules, i.e., plant alkaloids, alkylating agents, antimetabolites, radionuclides, antitumor antibiotics, monoclonal antibodies, cytokines, vaccines and nucleic acids (Alexiou and Jurgons 2007). The beginnings of magnetic nanoparticles as delivery systems for drug delivery in the treatment of cancer date back to the late 1970 s. However, SPIONs for cancer gene delivery have only recently emerged as novel products of an interdisciplinary approach, linking expertise of chemistry, biology, medicine and physics (Scherer et al. 2002; Senyei et al. 1978; Widder et al. 1979). A promising method for gene delivery by SPIONs is magnetofection, which is defined as enhanced delivery of nucleic acids that are associated with SPIONs into cells under the influence of an external magnetic field (Plank et al. 2003; Scherer et al. 2002). Several reports have demonstrated enhanced transfection of reporter genes into different cell lines in vitro (Kamau et al. 2006; Kamau-Chapman et al. 2008; Krötz et al. 2003a, b; Scherer et al. 2002; Xiang et al. 2003). In addition, magnetofection contributed to site-specific delivery of antisense oligonucleotides as well as reporter genes attached to SPIONs in vivo (Krötz et al. 2003a; Scherer et al. 2002). Recently, two trials consisting of dose-escalation neoadjuvant gene therapy to surgery were performed in feline fibrosarcomas in which therapeutic genes were applied by magnetofection (Hüttinger et al. 2008; Jahnke et al. 2007). The use of SPIONs either as a drug or gene delivery system contributes to the effectiveness of the therapy in many ways. First, exploiting the magnetic field as the driving force for SPIONs results in a noninvasive therapeutic approach. A static magnetic field of moderate magnetic flux densities does not cause any known side effects, and therefore, patient compliance is high (Leszczynski 2005). Second, in cancer therapy, targeting of tumors with SPIONs by an external magnetic field increases the site specificity and, thus, selectivity of the therapy, which results in reduced side effects and lower cost of the therapy (Alexiou and Jurgons 2007).

There are several commercially available polymercoated SPIONs measuring 100-200 nm in diameter which have been used in many in vitro and some in vivo studies for magnetofection (Huth et al. 2004; Jahnke et al. 2007; Kim et al. 2006; Krötz et al. 2003a; Mykhaylyk et al. 2007a, 2009; Plank et al. 2003; Scherer et al. 2002). As reviewed by Gupta and Gupta (2005), physical properties of magnetic nanoparticles such as size, shape, hydrophilic nature, surface charge and magnetic behavior are responsible for their biodistribution and biocompatibility. Chemical properties such as composition of the core and coating are responsible for biocompatibility as well as for binding different molecules for therapeutic approaches and consequently therapeutic efficacy (Gupta and Gupta 2005). Various studies have reported more efficient membrane crossing and cellular uptake of smaller particles in comparison to larger ones, e.g., 10-20 nm vs. 1,000 nm and $70 \mathrm{~nm}$ vs. $200 \mathrm{~nm}$, regardless of their magnetic behavior (Prabha et al. 2002; Zauner et al. 2001). We developed our own method for SPION synthesis in order to prepare biocompatible SPIONs with a thin hydrophilic surface of controlled combined size of $<100 \mathrm{~nm}$ diameter (Drmota et al. 2008).

The aim of our study was to evaluate the physical and chemical properties of the custom-synthesized SPIONs for their potential use in magnetofection. Therefore, we evaluated their cytotoxicity, internalization and cellular trafficking pathways in different normal and malignant cells. The potential increase in cellular internalization of SPIONs was studied by exposure of different cells to an external magnetic field generated by different permanent magnets.

\section{Materials and Methods}

\section{Chemicals}

Iron(II) sulfate heptahydrate $\left(\mathrm{FeSO}_{4} \times 7 \mathrm{H}_{2} \mathrm{O}, 98 \%\right)$, iro$\mathrm{n}$ (III) sulfate hydrate $\left(\mathrm{Fe}_{2}\left[\mathrm{SO}_{4}\right]_{3} \times \mathrm{H}_{2} \mathrm{O}\right.$, reagent grade), tetraethyl orthosilicate (TEOS) $\left(\mathrm{C}_{2} \mathrm{H}_{5} \mathrm{O}\right)_{4} \mathrm{Si}$, cyclohexane $\left(\mathrm{C}_{6} \mathrm{H}_{12}, \mathrm{ACS}, 99+\%\right)$ and citric acid $\left(\mathrm{C}_{6} \mathrm{H}_{8} \mathrm{O}_{7}, 99+\%\right)$ were obtained from Alfa Aesar (Ward Hill, MA). Ammonium hydroxide solution $\left(\mathrm{NH}_{4} \mathrm{OH}\right)$, sodium $n$-dodecyl sulfate (SDS) $\left(\mathrm{CH}_{3}\left[\mathrm{CH}_{2}\right]_{11} \mathrm{OSO}_{3} \mathrm{Na}, 90 \%\right)$, 1-butanol $\left(\mathrm{CH}_{3}\left[\mathrm{CH}_{2}\right]_{3} \mathrm{OH}, 99+\%\right)$ and $99.8 \%$ ethanol $\left(\mathrm{CH}_{3} \mathrm{CH}_{2} \mathrm{OH}\right.$, absolut puriss. p.a.) were purchased from Sigma-Aldrich (St. Louis, MO). Sodium chloride $(\mathrm{NaCl}, 0.9 \%)$ solution, i.e., physiological saline solution, was obtained from B. Braun (Melsungen, DE).

\section{Synthesis of Silica-Coated SPIONs}

SPIONs were synthesized by precipitation in a reverse (water-in-oil [W/O]) microemulsion system water/SDS, 1-butanol/cyclohexane according to our previously described procedures with a few modifications (Drmota et al. 2008). Coating with silica was performed by a modified Stöber method (Stöber et al. 1968). In brief, two W/O microemulsions (ME I and ME II) were prepared. The water phase of ME I contained a $0.4 \mathrm{M}$ aqueous solution of 
$\mathrm{Fe}^{2+} / \mathrm{Fe}^{3+}$ with a ratio of $1 / 1.7$, whereas the water phase of ME II contained a 5\% ammonium hydroxide solution as the precipitation agent. The size of the reverse micelles was thermodynamically determined by the water-to-surfactant molar ratio $\left(w_{0}=5.3\right)$ and temperature $\left(\mathrm{T}=50^{\circ} \mathrm{C}\right)$. The mixture of ME I and ME II was placed in a thermostatic bath with magnetic stirring. After $1 \mathrm{~h}$, TEOS was added, leaving the mixture of ME I and ME II under the same conditions for another $24 \mathrm{~h}$. The precipitated SPIONs were then washed with a mixture of ethanol and water and centrifuged (Eppendorf 5810, Hamburg, DE) at 2,500 rpm for $3 \mathrm{~min}$, followed by washing with water only and centrifuging at 5,000 and $7,500 \mathrm{rpm}$ for 5 and $15 \mathrm{~min}$, respectively. Thereafter, SPIONs were dispersed in either distilled water or $0.9 \% \mathrm{NaCl}$ solution to obtain a ferrofluid (magnetic liquid). After adjusting the $\mathrm{pH}$ and ionic strength of the ferrofluid to the physiological range with $0.1 \mathrm{M}$ citric acid, $\mathrm{pH}$ was measured immediately and $1-4$ months later. The ferrofluid remained intact for 1 day in order to eliminate potential aggregates by separating the liquid phase from the sediment. Then, SPIONs were sterilized in an autoclave at $121^{\circ} \mathrm{C}$ for $15 \mathrm{~min}$ (A-21CA; Kambic Laboratory Equipment, Semic, Slovenia).

\section{Cell Lines}

Human melanoma SK-MEL-28 cells (ATCC, Manassas, VA) and mouse L929 fibroblasts (ATCC) were maintained in advanced minimum essential medium (MEM; Invitrogen-GIBCO, Paisley, UK), supplemented with $2 \%$ fetal bovine serum (FBS, Invitrogen-GIBCO), glutamax (10 ml/ 1, Invitrogen-GIBCO), penicillin (100 U/ml; Grünenthal, Aachen, DE) and gentamicin ( $50 \mu \mathrm{g} / \mathrm{ml}$; Krka, Novo mesto, Slovenia). Human mesothelial MeT-5A cells (ATCC) were maintained in advanced RPMI 1640 (Invitrogen-GIBCO), supplemented with $4 \%$ FBS and the same quantity of glutamax, penicillin and gentamicin as described above. Cells were incubated in a humidified atmosphere of $5 \% \mathrm{CO}_{2}$ at $37^{\circ} \mathrm{C}$ (Sanyo Electric Biomedical, Osaka, Japan). Cells were grown in Petri dishes of $15 \mathrm{~cm}$ diameter until they reached at least $80 \%$ confluence. Thereafter, the medium was removed. Cells were washed with phosphate-buffered saline (PBS) and detached with $0.25 \%$ trypsin/EDTA in Hank's buffer (Invitrogen-GIBCO). An equal volume of medium with FBS for trypsin inactivation was then added, and cells were collected, centrifuged and counted. All laboratory plastic was obtained from Techno Plastic Products (Trasadingen, Switzerland).

\section{Study Design}

Custom-synthesized SPIONs were tested for their physical and chemical properties. We evaluated their cytotoxicity, internalization and cellular trafficking pathways in different normal and malignant cells. The potential increase in cellular uptake of SPIONs was studied by exposure of cells to an external magnetic field generated by different permanent magnets.

\section{Characterization of Physicochemical Properties of SPIONs}

Size and shape were evaluated using transmission electron microscopy (TEM) (2000 FX with EDS AN10000; JEOL, Tokyo, Japan). Crystalline compounds were determined using X-ray diffractometry (XRD) (AXS, D5005; Bruker, Billerica, MA). The mean crystallite size was calculated according to the broadening of the characteristic peak of the XRD pattern using the Debye-Scherrer formula (Patterson 1939). Using a magnetometer, mass magnetization was measured and a hysteresis loop was obtained. The

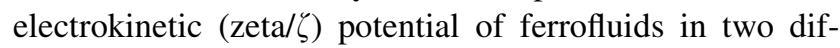
ferent aqueous media was measured by a zetameter (ZetaPALS; Brookhaven Instruments, New York, NY). The $\mathrm{pH}$ of the ferrofluid containing SPIONs in $0.9 \% \mathrm{NaCl}$ solution was measured by a $\mathrm{pH}$ meter (S47 K; Mettler Toledo, Greifensee, Switzerland). The concentration of iron oxide in SPIONs was determined by thermogravimetric analysis (Mettler Toledo, HB43).

\section{Cytotoxicity}

To evaluate the cytotoxicity of SPIONs alone, $1.5 \times 10^{4}$ cells $/ \mathrm{ml}$ were plated in $90 \mu \mathrm{l}$ of cell culture medium on clear-bottomed, 96-well plates and the MTS assay was performed. Ferrofluid was diluted with the cell culture medium so that SPIONs were added to the cells in the following concentrations: $12.5,25,50,100$ and $200 \mu \mathrm{g} / \mathrm{ml}$. Cell survival was determined $72 \mathrm{~h}$ posttreatment with SPIONs by the MTS assay as described above. The survival of cells treated with SPIONs is presented as the percentage of the absorbancy obtained from untreated control cells.

In addition, the reproductive potential of cells following treatment with SPIONs was determined by a clonogenic assay. We plated 50 cells $/ \mathrm{ml}$ in $4 \mathrm{ml}$ of cell culture medium on Petri dishes $6 \mathrm{~cm}$ in diameter. SPIONs were added to the cells at the same concentrations as described above. After 8 days of incubation, colonies were stained, fixed and counted. The survival of cells treated with SPIONs is presented as a cell surviving fraction of the ratio between the plating efficiency of treated cells and the plating efficiency of untreated control cells.

To evaluate the cytotoxicity of neodymium-iron-boron (Nd-Fe-B) magnets alone, (Supermagnete, Uster, Switzerland), $1.5 \times 10^{4}$ cells $/ \mathrm{ml}$ were plated in $90 \mu \mathrm{l}$ of cell culture medium on clear-bottomed, 96-well plates in every 
second well, followed by two empty columns to avoid the influence of neighboring magnets on the magnetic flux density (B) and magnetic gradient $(\mathrm{G})$. Nd-Fe-B magnets with surface $B=245 \mathrm{mT}$ and $\mathrm{G}=40 \mathrm{~T} / \mathrm{m}$ were placed below the plates for different lengths of time $(0,15,30,45$, 60 and $90 \mathrm{~min}$ ). Cell survival was determined $72 \mathrm{~h}$ after exposure to magnets by adding $20 \mu \mathrm{l}$ of MTS (3-[4, 5-dimethlythiazol-2-yl]-5-[3-carboxymethoxyphenyl]-2-[4sulfophenyl]-2H-tetrazolium) reagent (Promega, Madison, WI) to the cells. After $2 \mathrm{~h}$ incubation, the absorbance of formed formazan product was quantified using a spectrophotometer (Anthos Ht II; Biochrom, Cambridge, UK) at $492 \mathrm{~nm}$. The survival of cells exposed to $\mathrm{Nd}-\mathrm{Fe}-\mathrm{B}$ magnets is presented as a percentage of the absorbancy obtained from untreated control cells.

To evaluate the cytotoxic effect on MeT-5A, L929 and SK-MEL-28 cells treated with SPIONs while exposed to $\mathrm{Nd}-\mathrm{Fe}-\mathrm{B}$ magnets, a clonogenic assay was performed. We plated 100 MeT-5A, 50 L929 and 50 SK-MEL-28 cells were plated in $900 \mu \mathrm{l}$ of cell culture medium on clearbottomed, 24-well plates. Ferrofluid was diluted with the cell culture medium to obtain SPION concentrations of $12.5,25,50$ and $100 \mu \mathrm{g} / \mathrm{ml}$, which were added to the cells. $\mathrm{Nd}-\mathrm{Fe}-\mathrm{B}$ magnets with surface $\mathrm{B}=403 \mathrm{mT}$ and $\mathrm{G}=38$ $\mathrm{T} / \mathrm{m}$ were then placed below the cells treated with SPIONs for $0,15,30,45,60$ or $90 \mathrm{~min}$. After 8 days of incubation, colonies were stained, fixed and counted. The survival of cells treated with SPIONs while exposed to Nd-Fe-B magnets for a certain length of time is presented as the cell surviving fraction of the ratio between the plating efficiency of treated cells and that of untreated control cells.

\section{Cellular Uptake}

For qualitative and semiquantitative determination using a pulse-chase approach (Alberts et al. 2002), $4 \times 10^{5}$ cells/ $\mathrm{ml}$ (MeT-5A), $1.5 \times 10^{5}$ cells $/ \mathrm{ml}$ (L929) or $2.5 \times 10^{5}$ cells/ $\mathrm{ml}$ (SK-MEL-28) were plated in $90 \mu \mathrm{l}$ of cell culture medium on clear-bottomed, 96-well plates to $70 \%$ confluence. After $24-48 \mathrm{~h}$ of incubation, $100 \mu \mathrm{g}$ of SPIONs $/ \mathrm{ml}$ were added to each well. The medium of the pulse group was aspirated $1 \mathrm{~h}$ postincubation, whereas the pulse-chase group was left in cell culture medium without SPIONs for another $3 \mathrm{~h}$. After medium removal, cells were washed three times with PBS. Cells were fixed in a mixture of $4 \%$ $(\mathrm{w} / \mathrm{v})$ paraformaldehyde and $2.5 \%(\mathrm{v} / \mathrm{v})$ glutaraldehyde in $0.1 \mathrm{M}$ cacodylate buffer, $\mathrm{pH} 7.4$, for $1 \mathrm{~h}$ at $4^{\circ} \mathrm{C}$. Postfixation was carried out in $1 \%$ osmium tetroxide $\left(\mathrm{OsO}_{4}\right)$ in $0.1 \mathrm{M}$ cacodylate buffer for $2 \mathrm{~h}$, followed by dehydration in graded ethanols and embedding in Epon 812 resin. Ultrathin sections $(60 \mathrm{~nm})$ were cut, counterstained with uranyl acetate and lead citrate and examined with a TEM (CM100; Philips, Amsterdam, the Netherlands).
For quantitative determination of SPIONs in cells, iron content was measured by inductively coupled plasma atomic emission spectroscopy (ICP-AES). We plated $2.5 \times$ $10^{6}$ cells $/ \mathrm{ml}$ (MeT-5A), $0.5 \times 10^{6}$ cells $/ \mathrm{ml}$ (L929) or $1.5 \times$ $10^{6}$ cells/ml (SK-MEL-28) in $900 \mu \mathrm{l}$ of cell culture medium on clear-bottomed, 24-well plates to $90 \%$ confluence. After $24 \mathrm{~h}$ of incubation, $100 \mu \mathrm{g}$ of SPIONs/ml were added to each well. Ceramic and $\mathrm{Nd}-\mathrm{Fe}-\mathrm{B}$ magnets with surface $\mathrm{B}=60 \mathrm{mT}$ and $\mathrm{B}=403 \mathrm{mT}$ and $\mathrm{G}=5.5 \mathrm{~T} / \mathrm{m}$ and $\mathrm{G}=38$ $\mathrm{T} / \mathrm{m}$, respectively, were placed below the plates. After certain incubation times $(0,15,30,45,60$ and $90 \mathrm{~min})$, magnets were removed, the medium was aspirated and the wells were washed three times with PBS. Thereafter, cells were trypsinized, collected in $4.5-\mathrm{ml}$ cryo tubes and stored at $-18^{\circ} \mathrm{C}$. Prior to analysis, samples were equilibrated to room temperature and digested with a mixture of $0.2 \mathrm{ml}$ $65 \%$ nitric acid and $0.2 \mathrm{ml} 30 \%$ hydrogen peroxide by incubation at $90^{\circ} \mathrm{C}$ for at least $24 \mathrm{~h}$ to obtain clear solutions. Samples were then diluted with water to $4 \mathrm{ml}$. The iron concentration in digested samples was determined by ICPAES on a Perkin-Elmer (Norwalk, CT) plasma 40 emission spectrometer at a wavelength of $259.94 \mathrm{~nm}$.

\section{Statistical Analysis}

Each experiment was carried out at least in triplicate. Data are presented as means \pm standard errors. Differences between mean values of two groups and more than two groups were tested for significance by Student's $t$-test and one-way analysis of variance (ANOVA), followed by the Holm-Sidak test, respectively. $P \leq 0.05$ was considered significant. Sigma Plot, version 11, statistical software (Systat Software, San Jose, CA) was used for statistical analysis.

\section{Results}

Characterization of Physicochemical Properties of Silica-Coated SPIONs

SPIONs were synthesized by precipitation in a reverse (W/ O) microemulsion and coated with silica using a modified Stöber method. After synthesis, SPIONs were dispersed in different aqueous media (distilled water and $0.9 \% \mathrm{NaCl}$ solution) to obtain a ferrofluid (magnetic liquid). Size, shape, crystalline compounds and magnetic properties of SPIONs, as well as $\mathrm{pH}$ and stability of ferrofluids, were determined by different methods.

Size and shape of SPIONs, as determined by TEM analysis, demonstrated spherical core shell-type nanoparticles. The particle size was estimated to be $12 \mathrm{~nm}$ in diameter $(11.60 \pm 1.48 \mathrm{~nm})$, with the iron oxide core being 


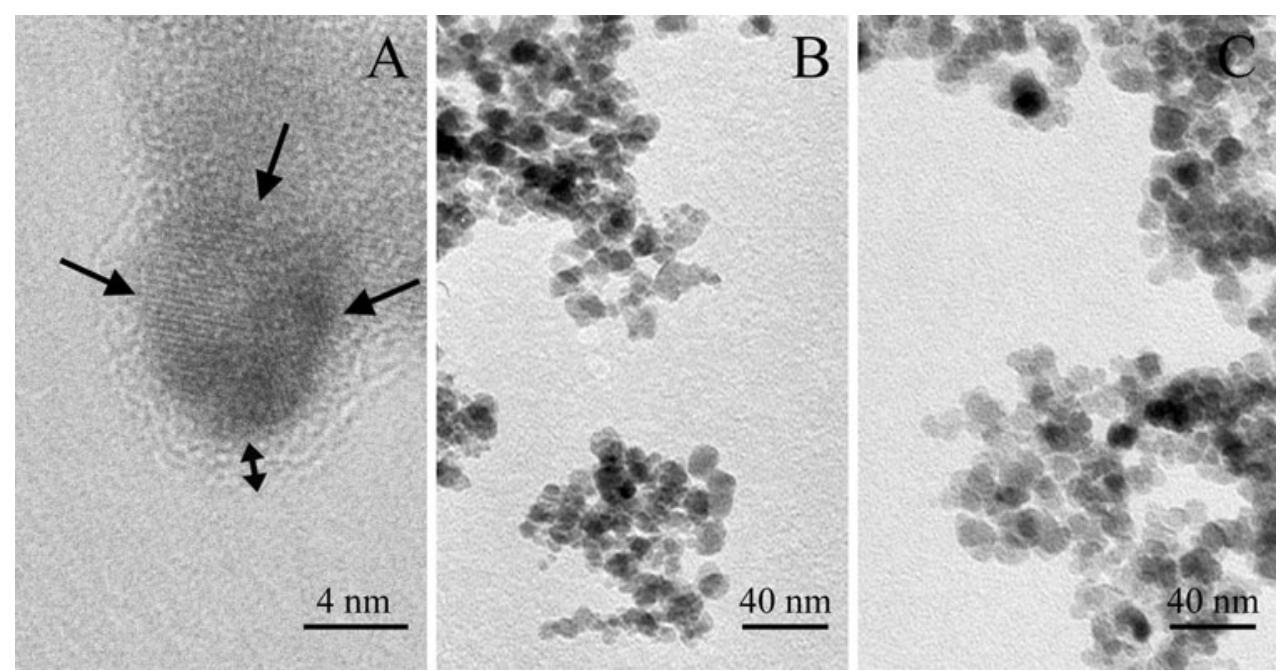

Fig. 1 TEM images of SPIONs. a Darker spherical area represents the core of a single nanoparticle measuring approximately $8 \mathrm{~nm}$ in diameter (arrows), coated with an approximately 2-nm-thick shell of silica on the surface (double arrow). SPIONs not autoclaved (b)

$8 \mathrm{~nm}$ and the silica coating $2 \mathrm{~nm}$ (Fig. 1). Ferrofluids used in biomedical applications have to be sterile. Sterilization of the ferrofluid by autoclaving did not change the size and shape of the SPIONs (Fig. 1).

Crystalline compounds of synthesized SPIONs were determined by XRD. SPIONs should be composed of iron oxide since the agent we used for precipitation from iro$\mathrm{n}(\mathrm{II})$ sulfate heptahydrate $\left(\mathrm{FeSO}_{4} \times 7 \mathrm{H}_{2} \mathrm{O}\right)$ and iron(III) sulfate hydrate $\left(\mathrm{Fe}_{2}\left[\mathrm{SO}_{4}\right]_{3} \times \mathrm{xH}_{2} \mathrm{O}\right)$ was ammonium hydroxide solution $\left(\mathrm{NH}_{4} \mathrm{OH}\right)$. The XRD pattern obtained confirmed iron oxide, most probably maghemite $\left(\gamma-\mathrm{Fe}_{2} \mathrm{O}_{3}\right)$, due to the value of mass magnetization and since magnetite $\left(\mathrm{Fe}_{3} \mathrm{O}_{4}\right)$ is less stable and more prone to oxidation (Fig. 2) (Kang et al. 1996; Makovec et al. 2005). Furthermore, we calculated mean crystallite size according to the

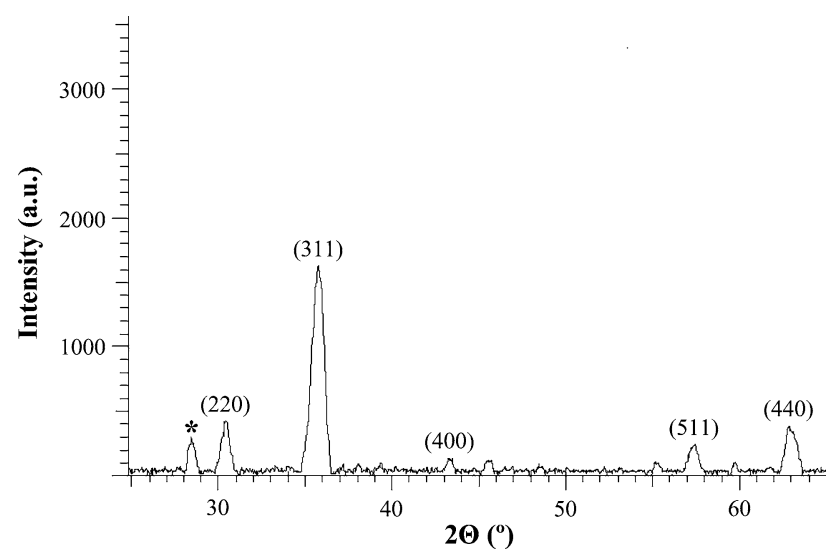

Fig. 2 X-ray diffractogram of SPIONs. The pattern shows characteristic peaks of iron oxide maghemite $\left(\gamma-\mathrm{Fe}_{2} \mathrm{O}_{3}\right)$. $*$ Peak possibly due to an $\mathrm{Fe}-\mathrm{Si}$ compound resembled those after autoclaving (c). Samples for TEM observations were prepared by placing ultrasonically agitated suspension onto lacy carbon-coated nickel grids. When drying, SPIONs tend to form agglomerates due to their high surface energy

broadening of the XRD characteristic peak 311 using the Debye-Sherrer formula, which was $9.2 \mathrm{~nm}$. This calculation of the iron core size is in accordance with the observations based on TEM images.

Magnetic properties of SPIONs were evaluated by a magnetometer. SPION mass magnetization as a function of an applied magnetic field at room temperature was $36.27 \pm$ $1.45 \mathrm{Am}^{2} / \mathrm{kg}$. The hysteresis loop obtained demonstrated superparamagnetic behavior of SPIONs due to zero coercivity (Fig. 3). The data indicate that magnetic properties of SPIONs are favorable for their use in biomedical applications-namely, SPIONs demonstrated magnetic

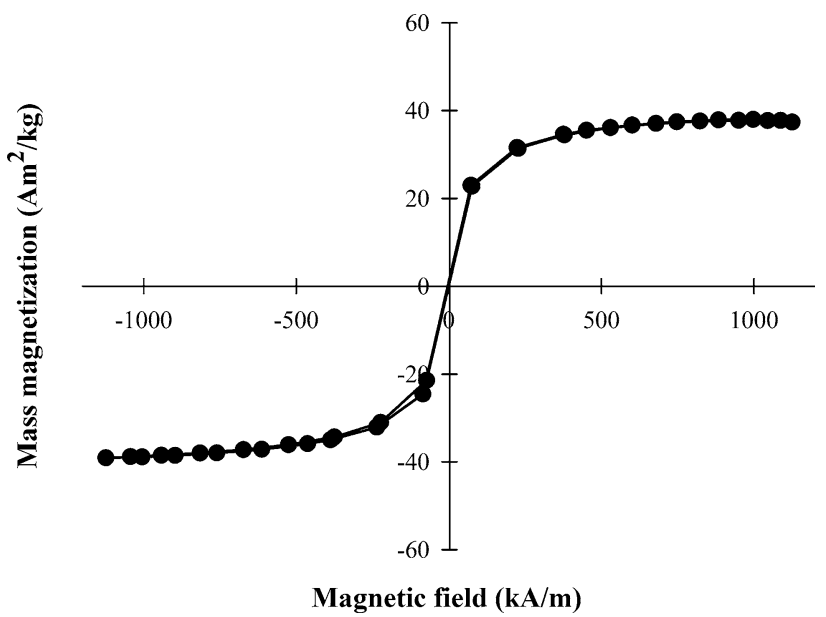

Fig. 3 Hysteresis loop of SPIONs obtained by a magnetometer. Mass magnetization and absence of magnetic behavior when not exposed to an external magnetic field indicate their suitability for use in biomedical applications. Data are presented for a representative sample 
behavior only in the presence of an applied external magnetic field.

The $\mathrm{pH}$ stability of the ferrofluid over a period of 4 months was measured by a $\mathrm{pH}$ meter. The $\mathrm{pH}$ of the ferrofluid (SPIONs dispersed in $0.9 \% \mathrm{NaCl}$ solution) after synthesis was not in the physiological range $(8.73 \pm 0.23)$. Therefore, we adjusted $\mathrm{pH}$ with $0.1 \mathrm{M}$ citric acid to $7.06 \pm$ 0.17. Adjustments of $\mathrm{pH}$ were stable from 1 to 4 months, with a minor increase in $\mathrm{pH}$ to $7.41 \pm 0.28$. The measurements demonstrated $\mathrm{pH}$ stability of the ferrofluids without statistically significant changes of $\mathrm{pH}$ after 14 months, indicating that ferrofluids can be prepared as a stock solution for several experiments at a certain time (Table 1).

The stability of ferrofluids in different aqueous media and isoelectric points were determined by a zetameter, measuring the zeta potential. Bare SPIONs without silica coating in distilled water exhibited an isoelectric point in the physiological $\mathrm{pH}$ range, which resulted in disruption of the stability of ferrofluid and formation of aggregates.

Table 1 The $\mathrm{pH}$ of the ferrofluid (SPIONs dispersed in $0.9 \% \mathrm{NaCl}$ solution) at the time of its preparation, after adjustment with $0.1 \mathrm{M}$ citric acid and after a few months

\begin{tabular}{llll}
\hline Sample & $\begin{array}{l}\mathrm{pH} \text { after } \\
\text { synthesis }\end{array}$ & $\begin{array}{l}\mathrm{pH} \text { after adjustment } \\
\text { with citric acid }\end{array}$ & $\begin{array}{l}\mathrm{pH} \text { after } \\
1-4 \text { months }\end{array}$ \\
\hline 1 & 8.72 & 6.91 & 7.12 \\
2 & 8.50 & 7.01 & 7.43 \\
3 & 8.96 & 7.24 & 7.69 \\
Mean $\pm \mathrm{SD}$ & $8.73 \pm 0.23$ & $7.06 \pm 0.17$ & $7.41 \pm 0.28$ \\
\hline
\end{tabular}

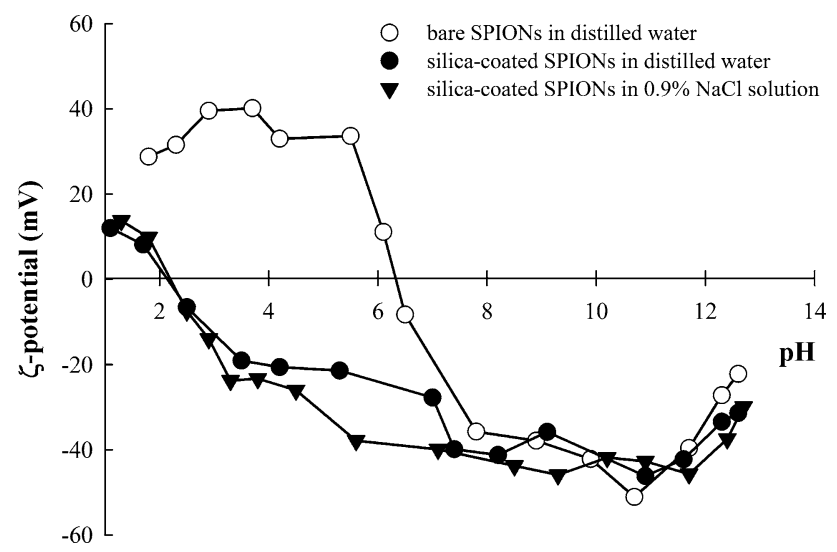

Fig. 4 Zeta potentials of ferrofluids in aqueous media (distilled water and $0.9 \% \mathrm{NaCl}$ solution), containing either bare or coated SPIONs. Bare SPIONs dispersed in distilled water exhibited an isoelectric point in the physiological $\mathrm{pH}$ range. Silica-coated SPIONs, dispersed in either distilled water or $0.9 \% \mathrm{NaCl}$ solution, exhibited a highly negative zeta potential, with isoelectric points in the acidic $\mathrm{pH}$ range
Coating SPIONs with silica shifted the isoelectric point of the ferrofluid; i.e., SPIONs dispersed in either distilled water or $0.9 \% \mathrm{NaCl}$ solution well into the acidic $\mathrm{pH}$ range. In the physiological $\mathrm{pH}$ range, the zeta potential of ferrofluids containing silica-coated SPIONs was approximately $-40 \mathrm{mV}$, which suggests that ferrofluids of silicacoated SPIONs can be used in the physiological $\mathrm{pH}$ range (Fig. 4). Furthermore, this indicates a negative surface charge of the particles; therefore, this must be taken into account when they are functionalized with specific molecules.

\section{Cytotoxicity}

In order to use SPIONs in biomedical applications, their potential cytotoxicity should be evaluated. Two tests were employed: the MTS test, which measures cell viability, and a clonogenic assay, which determines the reproductive potential of cells. Mesothelial cells (MeT-5A), mouse fibroblasts (L929) and human melanoma cells (SK-MEL28) were exposed to different concentrations of SPIONs in $0.9 \% \mathrm{NaCl}$ solution, ranging $10-200 \mu \mathrm{g} / \mathrm{ml}$. Cell viability determined by the MTS assay displayed no cytotoxicity to all three cell lines exposed to different concentrations of SPIONs. However, the highest concentration tested reduced survival below $\mathrm{IC}_{50}$ (the concentration that reduces the survival of cells by $50 \%$ ) for MeT-5A cells only (Fig. 5).

The reproductive potential of MeT-5A, L929 and SKMEL-28 cells was determined by a clonogenic assay. No statistically significant reduction in survival of L929 and SK-MEL-28 cells in comparison to untreated control cells was observed at almost all concentrations of SPIONs. SPIONs decreased survival of L929 and SK-MEL-28 cells when added at the highest concentrations, which was, however, still above $\mathrm{IC}_{50}$. In contrast, survival of MeT-5A cells in comparison to untreated control cells was statistically significantly decreased with exposure to all concentrations of SPIONs. However, concentrations $>50 \mu \mathrm{g} / \mathrm{ml}$ reduced survival by $>50 \%$ (Fig. 5).

In order to determine the potential cytotoxic effect of $\mathrm{Nd}-\mathrm{Fe}-\mathrm{B}$ magnets, the viability of all three cell lines was assessed by the MTS assay at different durations of exposure to an external magnetic field. There was no statistically significant decrease in survival of all three cell lines compared to the unexposed control group at all time intervals (Fig. 6).

To determine the potential cytotoxic effect of SPIONs and Nd-Fe-B magnets on MeT-5A, L929 and SK-MEL-28 cells, a clonogenic assay was performed. A statistically significant decrease in survival of L929 and SK-MEL-28 cells was obtained predominantly at the highest concentration of SPIONs $(100 \mu \mathrm{g} / \mathrm{ml})$ irrespective of the length of 
Fig. 5 Cytotoxicity of SPIONs to mesothelial MeT-5A cells, mouse L929 fibroblasts and human melanoma SK-MEL-28 cells by the MTS assay (a) and concentrations $>50 \mu \mathrm{g} / \mathrm{ml}$ significantly affected cell MeT-5A cells $(* P \leq 0.05$ vs. untreated control cells) clonogenic assay (b). SPIONs at growth, predominantly for
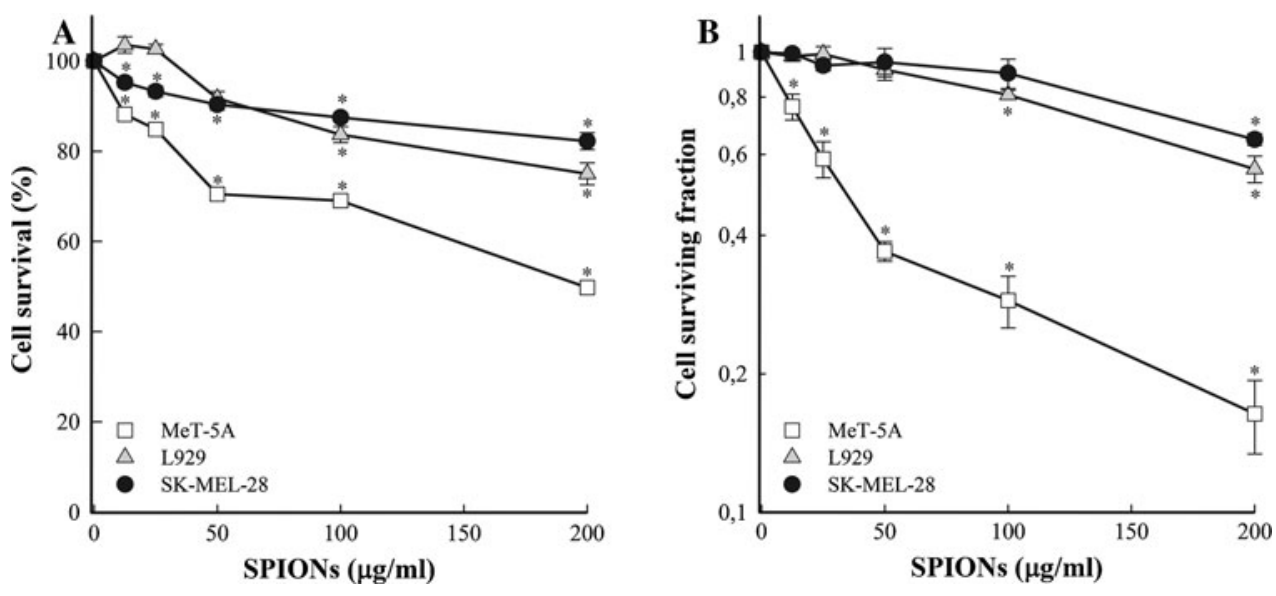

Fig. 6 a Cytotoxicity to MeT5A, L929 and SK-MEL-28 cells exposed to $\mathrm{Nd}-\mathrm{Fe}-\mathrm{B}$ magnets at different time intervals. Cytotoxicity of SPIONs to MeT-5A (b), L929 (c) and SKMEL-28 (d) cells with additional exposure to $\mathrm{Nd}-\mathrm{Fe}-\mathrm{B}$ magnets for different time intervals. a When exposed to $\mathrm{Nd}-\mathrm{Fe}-\mathrm{B}$ magnets only, no statistically significant decrease in cell survival for all three cell lines was observed. b At longer exposures to $\mathrm{Nd}-\mathrm{Fe}-\mathrm{B}$ magnets (60 and $90 \mathrm{~min}$ ), concentrations of SPIONs $>25 \mu \mathrm{g} / \mathrm{ml}$ statistically significantly decreased survival of MeT-5A cells. c, $\mathbf{d}$ The highest concentrations of SPIONs (50 and $100 \mu \mathrm{g} / \mathrm{ml}$ ) significantly decreased survival of L929 and SK-MEL-28 cells independently of the duration of exposure to an external magnetic field $(P \leq$ 0.05 vs. untreated control cells; for the purpose of clarity, we omitted asterisks representing statistically significant differences)
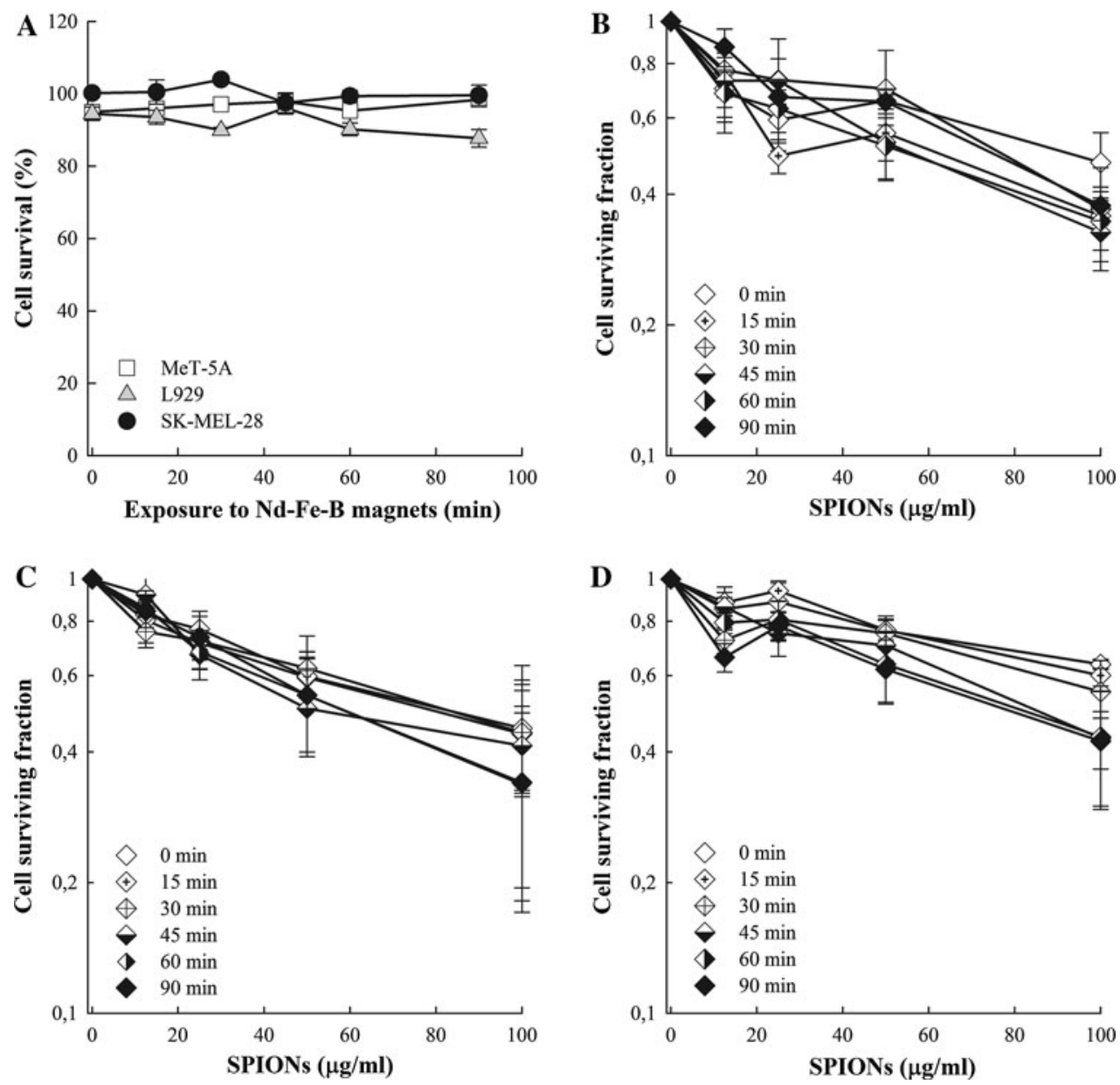

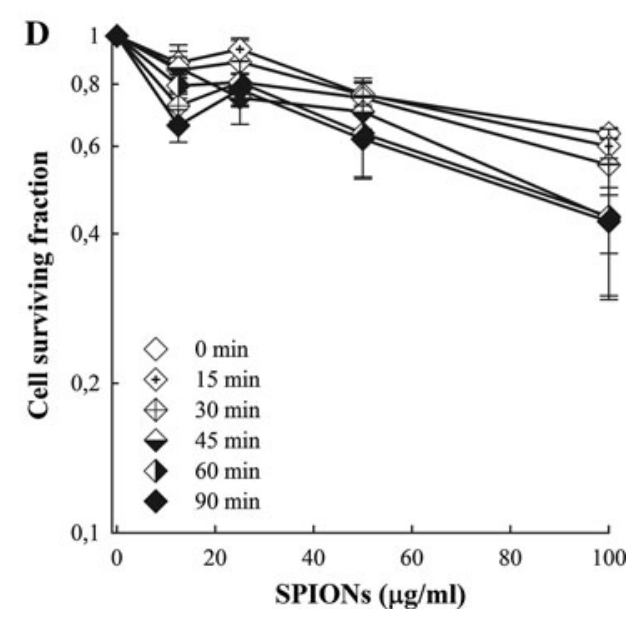

exposure to an external magnetic field. MeT-5A cells were more susceptible to the combination of SPIONs and an external magnetic field. Reduction in their survival was obtained by longer exposures to an external magnetic field (60 and $90 \mathrm{~min})$, also at a low concentration $(25 \mu \mathrm{g} / \mathrm{ml})$ of SPIONs (Fig. 6).
Cellular Uptake

SPIONs as potential delivery systems should be able to be internalized into different types of cells, in the greatest amount and as fast as possible. Qualitative, semiquantitative and quantitative analyses of internalized SPIONs were 
Fig. 7 TEM images of a mesothelial MeT-5A cell (a), a mouse L929 fibroblast (b) and a human melanoma SK-MEL-28 cell (c) after 1-h incubation (pulse group). a Caveola-like structure is observed (arrow). b Endosomes have the morphology of MVBs (arrows). c Endocytotic-degradative compartments, involved in internalization and trafficking of SPIONs (arrows)
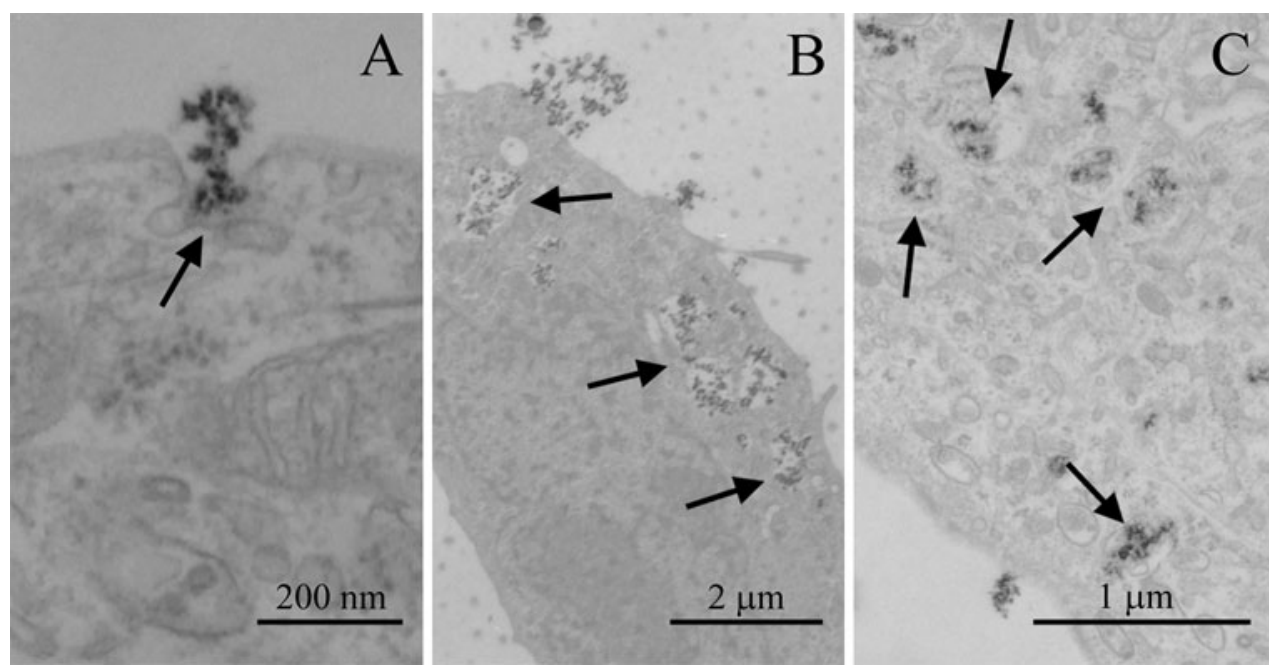

performed by TEM and ICP-AES, measuring the iron content.

Qualitative and semiquantitative determination of internalization and cellular trafficking pathways of SPIONs in MeT-5A, L929 and SK-MEL-28 cells were evaluated by TEM using a pulse-chase approach. A particular cell line was exposed to $100 \mu \mathrm{g}$ of SPIONs/ml for the $1 \mathrm{~h}$ pulse group, followed by incubation for another $3 \mathrm{~h}$ after SPION removal for the pulse-chase group. Cellular uptake of SPIONs was mediated by endocytosis. In all cell types, coated invaginations of the plasma membrane were detected, but they did not seem to contain SPIONs. Instead, caveolae-like structures were observed (Fig. 7). However, further studies are needed to determine the mechanism of internalization of SPIONs. In the pulse group, internalized SPIONs were observed throughout the endocytotic-degradative pathway, i.e., in endocytotic vesicles, endosomal compartments and lysosomes, in all tested cell lines (Fig. 7). Endosomes appeared as electron lucent multivesicular bodies (MVBs) with a varying number of internal vesicles, probably representing transition from early to late endosomes. In the pulsechase group, numerous enlarged endosomes were observed in all cell lines tested, which accumulated SPIONs in large amounts (Fig. 8).

Due to their magnetic behavior, SPIONs can be manipulated by an external magnetic field, which can be generated by different types of magnets. Therefore, two magnet types having different magnetic properties were used for the quantitative determination of SPIONs in different cell lines by ICP-AES. Ceramic and $\mathrm{Nd}-\mathrm{Fe}-\mathrm{B}$ magnets with surface magnetic flux density of 60 and 403 $\mathrm{mT}$ and magnetic gradient of 5.5 and $38 \mathrm{~T} / \mathrm{m}$, respectively, were used for 15-min exposure of MeT-5A, L929 and SKMEL-28 cells. Exposure of cells to an external magnetic field with either of the magnets statistically significantly increased cellular uptake of SPIONs (Fig. 9). Moreover, $\mathrm{Nd}-\mathrm{Fe}-\mathrm{B}$ magnets were statistically significantly more effective for the internalization process of SPIONs to all
Fig. 8 TEM images of a mesothelial MeT-5A cell (a), a mouse L929 fibroblast (b) and a human melanoma SK-MEL-28 cell (c) after prolonged 3-h incubation subsequent to SPION removal after 1-h incubation (pulse-chase group). a Accumulation of SPIONs in MVB (arrowheads) and lysosome (arrow). b Accumulation of SPIONs in endosomes (arrows). c Enlarged endosomes with high accumulation of SPIONs (arrows)
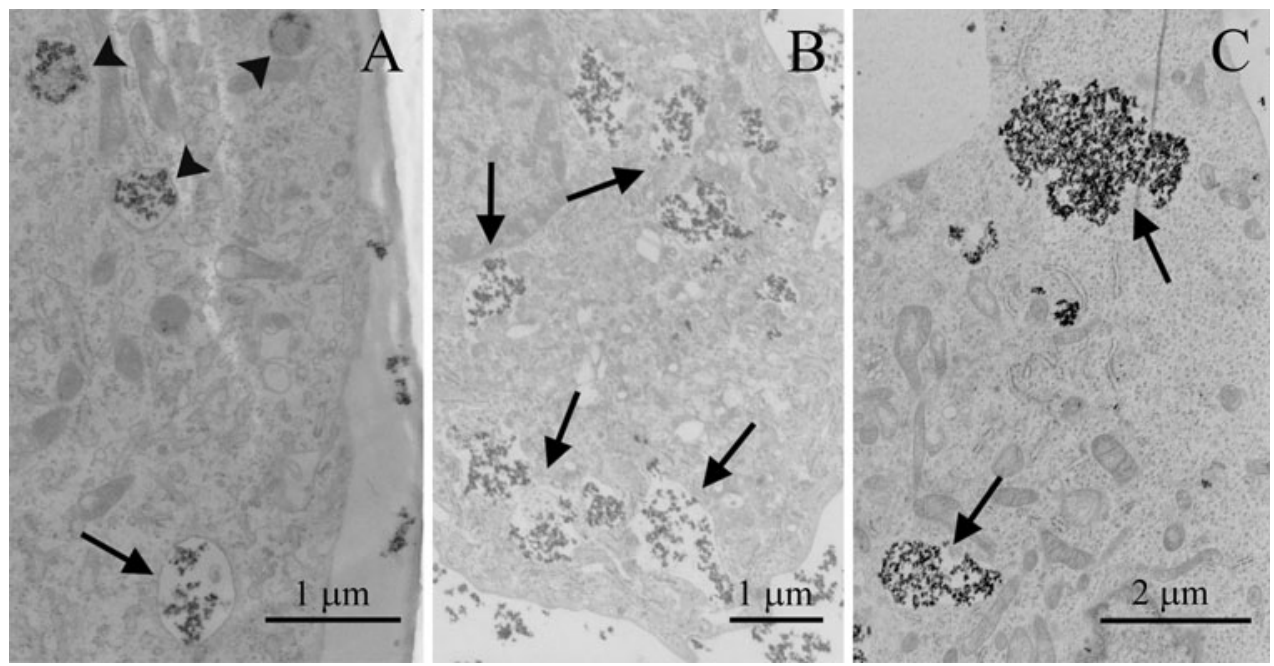


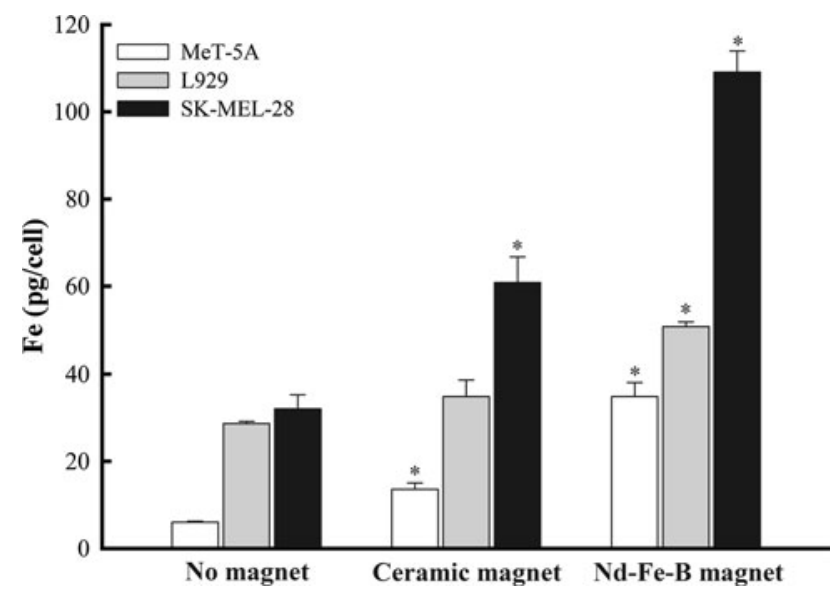

Fig. 9 Iron content in the cells represents the cellular uptake of SPIONs. A statistically significant increase in cellular uptake of SPIONs in the presence of either ceramic or Nd-Fe-B magnets compared to uptake in the absence of an external magnetic field was observed ( $* P \leq 0.05$ vs. no magnet)

cell lines in comparison to ceramic magnets. Depending on the cell type, $\mathrm{Nd}-\mathrm{Fe}-\mathrm{B}$ magnets were 1.5- to 2.6-fold more effective in the internalization of SPIONs than ceramic magnets. Furthermore, there was a difference in internalization between the cell types: the highest amount of internalized SPIONs was observed in SK-MEL-28 cells, followed by L929 and MeT-5A.

To determine time-dependent cellular uptake of SPIONs, MeT-5A, L929 and SK-MEL-28 cells were exposed to an external magnetic field, which was generated by $\mathrm{Nd}-\mathrm{Fe}-\mathrm{B}$ magnets, at different time intervals, ranging 0-90 min. When exposed to an external magnetic field, all three cell lines demonstrated a statistically significant increase in internalization of SPIONs compared to unexposed cells

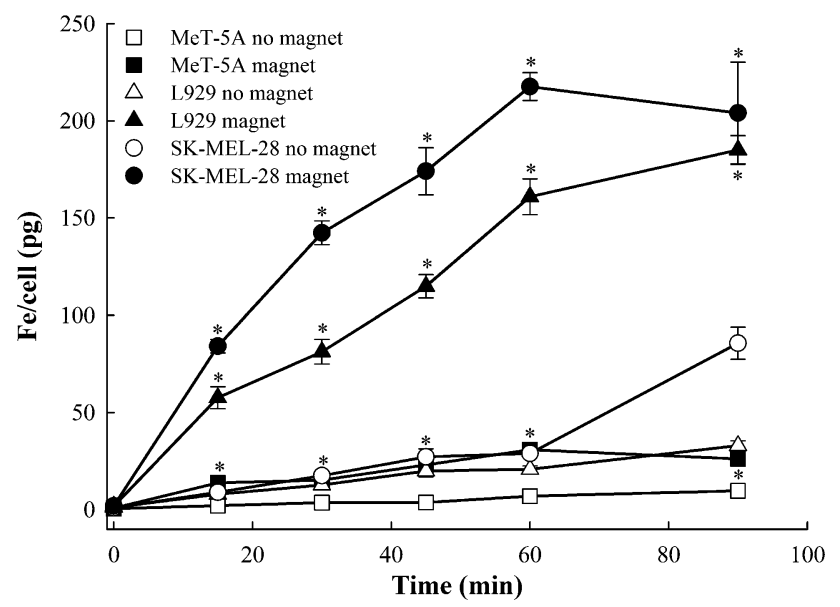

Fig. 10 Iron content in MeT-5A, L929 and SK-MEL-28 cells represents the cellular uptake of added $100 \mu \mathrm{g} / \mathrm{ml}$ of SPIONs. A statistically significant increase in cellular uptake of SPIONs in the presence of $\mathrm{Nd}-\mathrm{Fe}-\mathrm{B}$ magnets was observed in all cell lines tested (* $P \leq 0.05$ vs. no magnet)
(Fig. 10). However, for the time interval 0 min (SPIONs present for $<30 \mathrm{~s}$ ), the difference in cellular uptake of SPIONs between exposed and unexposed cells was not statistically significant. As already demonstrated (Fig. 9), a statistically significant difference in internalization between all three cell types was observed, except for the time interval $0 \mathrm{~min}$. The highest amount of internalized SPIONs was observed in SK-MEL-28 cells, followed by L929 and MeT-5A.

\section{Discussion}

Our results demonstrate that custom-synthesized SPIONs displayed adequate physicochemical and biomedical properties for their potential use in magnetofection of cells and tissues in vivo. SPIONs were demonstrated to be spherical maghemite nanoparticles with a diameter of 8-9 nm, coated with a 2-nm-thick layer of silica. Their magnetic properties were in agreement with their size and the type of coating and were expressed only in the presence of an external magnetic field. SPIONs dispersed in a $0.9 \% \mathrm{NaCl}$ solution resulted in a stable ferrofluid with physiological $\mathrm{pH}$, which was noncytotoxic in a broad range of concentrations. Endocytosis-mediated internalization of SPIONs was more efficient in malignant than normal cells and was dependent on the duration of magnetic field exposure.

The type of initial chemicals, as well as the type of synthesis process, determines the majority of physical properties of SPIONs. We chose unique biocompatible chemicals for the synthesis of SPIONs by precipitation in a reverse $(\mathrm{W} / \mathrm{O})$ microemulsion. Using this method, the particle size is indirectly controlled by the thermodynamically determined size of the water droplets, i.e., reverse micelles, where the particles precipitate (Pileni 1993). Reverse micelles are distributed apart from each other within the oily phase with the help of different types of cationic, anionic or non-ionic surfactants (Capek 2004; Makovec et al. 2005; Vidal-Vidal et al. 2006). We synthesized SPIONs which were $12 \mathrm{~nm}$ in diameter by precipitation from iron(II) and iron(III) sulfates in a W/O microemulsion using SDS as the surfactant. Therefore, we developed a unique and efficient method for synthesis of SPIONs which are smaller than commercially available ones, e.g., PolyMag and CombiMag.

A relatively large surface area in comparison to the volume makes SPIONs more susceptible to reaction with other molecules rather than the bulk material, which can lead to toxicity (Thassu et al. 2007). Hence, in addition to using biocompatible initial chemicals, coating of SPIONs with an appropriate material is crucial to prevent toxic effects (McBain et al. 2008). Moreover, the hydrophilic surface is of great importance in avoiding the clearance of 
SPIONs by mononuclear phagocytic cells of the reticuloendothelial system from the bloodstream (Storm et al. 1995), as well as increasing cellular uptake (Gupta and Gupta 2005; Petri-Fink et al. 2005; Wilhelm et al. 2003). In our study, SPIONs were coated with TEOS using a modified Stöber method, which resulted in a 2-nm-thick layer of a nontoxic, indigestible and hydrophilic silica surface (Brunner et al. 2006; Ulman 1996). Other studies have also reported on similar thickness of the silica coating using the same coating method (Makovec et al. 2009; Maver et al. 2009).

The type and thickness of the coating, as well as the size of SPIONs, determine their magnetic properties ( $\mathrm{Lu}$ et al. 2007). A thinner coating and larger size of particles contribute to higher magnetization and vice versa (Gupta and Gupta 2005). Mass magnetization of our silica-coated SPIONs was $36.27 \pm 1.45 \mathrm{Am}^{2} / \mathrm{kg}$, which was approximately $50 \%$ higher than magnetization of the glucosaminic acid-modified magnetic nanoparticles of the same size ( $\mathrm{Yu}$ et al. 2008). However, our results correlated with the magnetization of silica-coated SPIONs of the same size produced by others (Makovec et al. 2009; Maver et al. 2009). The superparamagnetic behavior of SPIONs was inferred due to zero coercivity. This correlated with the determined size of SPIONs by TEM and XRD since, as reviewed by Gupta and Gupta (2005), only particles of the order below $15 \mathrm{~nm}$ display superparamagnetic behavior.

The indirect toxicity of SPIONs depends on the type of aqueous medium in which the material is dispersed, as well as on the $\mathrm{pH}$ value of the obtained dispersion (Sincai et al. 2002). After synthesis, we dispersed SPIONs into an isotonic medium, $0.9 \% \mathrm{NaCl}$ solution, to obtain a ferrofluid (magnetic liquid) appropriate for use in biomedical applications. We adjusted $\mathrm{pH}$ using citric acid, and the resulting dispersion was stable from 1 to 4 months without a statistically significant increase in $\mathrm{pH}$. In the other studies, $\mathrm{pH}$ adjustments were performed just by dispersing SPIONs into different isotonic solutions (Dormer et al. 2005; Wilhelm et al. 2003). However, no reports on the long-term stability of $\mathrm{pH}$ of ferrofluids for use in biomedical applications exist.

The surface charge of nanoparticles influences their stability as well as the cellular internalization and trafficking pathways (Harush-Frenkel et al. 2008; Hunter 2001). In the case of ferrofluids, direct measurement of the surface charge of SPIONs is impossible due to their small size. Instead, the zeta potential measurement yields information for calculation of the surface charge (Hunter 2001). In our study, the zeta potential of the ferrofluid (silicacoated SPIONs in $0.9 \% \mathrm{NaCl}$ ) at physiological $\mathrm{pH}$ was approximately $-40 \mathrm{mV}$, which indicates good stability without formation of aggregates. The negative sign indicates the anionic nature of SPIONs, which was reported to contribute to 3-fold more efficient cellular uptake than that observed with cationic SPIONs and was comparable to Tat peptide-modified nanoparticles (Josephson et al. 1999; Wilhelm et al. 2003).

Ferrofluids used in biomedical applications have to be sterile. Since various sterilization methods, i.e., filtration, $\gamma$-irradiation and chemical sterilization, resulted in changes of physicochemical properties of nanoparticles or toxic chemical residues (Müller 1991; Sommerfeld et al. 1998), autoclaving was chosen as the sterilization method. As is evident from the TEM images, sterilization of SPIONs by autoclaving did not result in any changes of their size and shape. Similarly, Bahadur et al. (2005) autoclaved ferrofluids; however, no observations on the consequences of sterilization on alterations of the amount and properties of SPIONs were reported.

SPIONs were first used as contrast agents for MR imaging 35 years ago (Webb 1988) and have been to date the only magnetic nanoparticles approved for clinical use. However, toxicity of SPIONs predominantly depends on their surface properties (Brunner et al. 2006). We observed no cytotoxicity of silica-coated SPIONs to human melanoma SK-MEL-28 cells and mouse L929 fibroblasts when added in different concentrations measured by the MTS and clonogenic assays. However, the highest concentration tested $(200 \mu \mathrm{g} / \mathrm{ml})$ reduced the survival of MeT-5A cells below $\mathrm{IC}_{50}$ by the MTS assay. Moreover, as determined by a clonogenic assay, concentrations of SPIONs $>50 \mu \mathrm{g} / \mathrm{ml}$ reduced survival of MeT-5A cells by $>50 \%$. These results suggest that MeT-5A cells are more sensitive to SPIONs than mouse L929 cells and malignant SK-MEL-28 cells. The same was demonstrated when the cells were exposed to the combination of SPIONs and an external magnetic field. Similarly, Brunner et al. (2006) observed cell typespecific cytotoxicity of uncoated SPIONs-namely, slower proliferating rodent fibroblasts (3T3) exhibited higher survival than fast-growing human mesothelioma cells (MSTO).

Cellular uptake of nanoparticles is mediated by endocytosis, beginning with invagination of the plasma membrane at either clathrin-coated pits or caveolae (Harush-Frenkel et al. 2008; Huth et al. 2004; Kim et al. 2006; Ma and Gu 2007; Petri-Fink et al. 2005). We observed that uptake of SPIONs into different cells was mediated by endocytosis. Moreover, invagination of the plasma membrane of MeT5A, L929 and SK-MEL-28 cells was initiated at the caveolae-like structures, which was also observed by others (Huth et al. 2004). When the cells with added SPIONs were left in the cell culture medium for $4 \mathrm{~h}$, enlarged endosomes with a high accumulation of SPIONs were observed, which indicates saturated accumulation of SPIONs. Aggregation of SPIONs observed prior to their internalization (Fig. 7) most probably occurred due to the composition of cell culture 
media and the amount of FBS added. MeT-5A cells were maintained in RPMI medium, which reportedly disrupted the colloidal stability of ferrofluids containing SPIONs, thus forming aggregates (Petri-Fink et al. 2008).

The kinetics of cellular uptake and potential saturated accumulation of SPIONs is cell type- as well as timedependent (Ma and Gu 2007; Wilhelm et al. 2003; Yu et al. 2008). According to our results, the highest iron content, representing internalized SPIONs, was measured in malignant SK-MEL-28 cells, followed by mouse L929 and MeT$5 \mathrm{~A}$ cells. These results correlated with the results of the study by Ma and Gu (2007), where malignant human lung cells internalized up to severalfold more SPIONs than normal lung cells. Also, other studies confirmed that malignant cells are more prone to internalization of magnetic nanoparticles than normal cells (Harutyunyan et al. 1999; Jordan et al. 1996; Ma and Gu 2007; Wilhelm et al. 2003; Yu et al. 2008). The reason is that malignant cells possess higher endocytotic potential than normal cells due to the enhanced requirement for nutrients by virtue of their high metabolic activity and proliferation rate (Sincai et al. 2000). After a certain incubation time of cells with SPIONs, saturated accumulation with plateau formation is reached (Wilhelm et al. 2003). In our study, a significant increase in their cellular uptake was detected in malignant SK-MEL-28 cells already within $90 \mathrm{~min}$ of incubation with SPIONs, whereas in MeT-5A cells 8.8-fold less iron was detected. Further incubation would lead to saturated accumulation, with malignant SK-MEL-28 cells reaching the plateau formation before normal MeT-5A cells. Similarly, several studies have demonstrated that malignant cells (ECA109, HEC-1B, HeLa) reached saturated accumulation before normal cells did (macrophages RAW264.7, fibroblasts 3T3) (Wilhelm et al. 2003; Yu et al. 2008).

Saturated accumulation is reached earlier when cells are exposed to an external magnetic field as the magnetic force increases the sedimentation of SPIONs onto the cellular surface (Luo and Saltzman 2000). According to our results, 2.7-fold more iron per cell ( $26.18 \pm 2.38 \mathrm{pg})$ was observed in normal MeT-5A cells after 90 -min exposure to Nd-Fe-B magnets in comparison to unexposed cells. On the other hand, malignant SK-MEL-28 cells, exposed to Nd-Fe-B magnets for $90 \mathrm{~min}$, internalized $204.12 \pm 26.15 \mathrm{pg}$ of iron, which is 2.4-fold more than unexposed cells. This result is in accordance with the maximum iron contents observed in different malignant cells after addition of $100 \mu \mathrm{g} / \mathrm{ml}$ of SPIONs below $30 \mathrm{~nm}$ but after a much longer incubation time (Ma and Gu 2007; Yu et al. 2008). However, no reports dealing with quantitative evaluation of SPION internalization with a size of 100-200 nm have been published. Our data suggest that malignant SK-MEL28 cells might have reached a plateau after $90 \mathrm{~min}$ of exposure to $\mathrm{Nd}-\mathrm{Fe}-\mathrm{B}$ magnets, which indicates that the presence of an external magnetic field increases cellular uptake of SPIONs.

Therefore, with supplementary functionalization by specific molecules containing positive functional groups, our custom-synthesized SPIONs can electrostatically interact with or covalently bind DNA. For example, different amines and imines containing nitrogen functional groups have already proven to efficiently link magnetic nanoparticles with nucleic acids, and it was demonstrated that these functionalized SPIONs can be effectively internalized into the cells (McBain et al. 2007; Mykhaylyk et al. 2007b; Taira et al. 2009).

In conclusion, our results demonstrate adequate physicochemical properties of biocompatible custom-synthesized SPIONs that show increased cellular uptake into malignant cells in the presence of an external magnetic field.

Acknowledgements The authors thank Mira Lavric for assisting with the cell cultures, Jure Koselj for helping with magnets and the magnetometer and Mireille Treeby for proofreading the manuscript. The authors acknowledge the financial support of the Slovenian Research Agency (program P3-0003).

Open Access This article is distributed under the terms of the Creative Commons Attribution Noncommercial License which permits any noncommercial use, distribution, and reproduction in any medium, provided the original author(s) and source are credited.

\section{References}

Alberts B, Johnson A, Lewis J et al (2002) Glossary. In: Alberts B, Johnson B, Lewis J, Raff M, Roberts K, Walter P (eds) Molecular biology of the cell, 4th edn. Garland Science, New York, p G:29

Alexiou C, Jurgons R (2007) Magnetic drug targeting. In: Andrä W, Nowak H (eds) Magnetism in medicine: a handbook, 2nd edn. Wiley-VCH, Berlin, pp 596-605

Bahadur D, Giri J, Nayak BB et al (2005) Processing, properties and some novel applications of magnetic nanoparticles. Pramana-J Phys 65:663-679

Brunner TJ, Wick P, Manser P et al (2006) In vitro cytotoxicity of oxide nanoparticles: comparison to asbestos, silica, and the effect of particle solubility. Environ Sci Technol 40:4374-4381

Capek I (2004) Preparation of metal nanoparticles in water-in-oil (w/ o) microemulsions. Adv Colloid Interface Sci 110:49-74

Dormer K, Seeney C, Lewelling K et al (2005) Epithelial internalization of superparamagnetic nanoparticles and response to external magnetic field. Biomaterials 26:2061-2072

Drmota A, Kosak A, Znidarsic A (2008) A microemulsion mediated synthesis of superparamagnetic core-shell nanoparticles for application in biomedicine. In: Nicolini C (ed) Nanotechnology $\&$ applications: proceedings of the IASTED international conference, September 29-October 1, 2008, Crete, Greece. Acta Press, Anaheim, CA, 4 pp

Gupta AK, Gupta M (2005) Synthesis and surface engineering of iron oxide nanoparticles for biomedical applications. Biomaterials 26:3995-4021 
Harush-Frenkel O, Rozentur E, Benita S et al (2008) Surface charge of nanoparticles determines their endocytic and transcytotic pathway in polarized MDCK cells. Biomacromolecules 9:435443

Harutyunyan AR, Kuznetsov AA, Kuznetsov OA et al (1999) Metalorganic magnetic materials based on cobalt phthalocyanine and possibilities of their application in medicine. J Magn Magn Mater 194:16-21

Hunter RJ (2001) Electrokinetics and the zeta potential. In: Hunter RJ (ed) Foundations of colloid science. Oxford University Press, New York, pp 373-434

Huth S, Lausier J, Gersting SW et al (2004) Insights into the mechanism of magnetofection using PEI-based magnetofectins for gene transfer. J Gene Med 6:923-936

Hüttinger C, Hirschberger J, Jahnke A et al (2008) Neoadjuvant gene delivery of feline granulocyte-macrophage colony-stimulating factor using magnetofection for the treatment of feline fibrosarcomas: a phase I trial. J Gene Med 10:655-667

Jahnke A, Hirschberger J, Fischer C et al (2007) Intra-tumoral gene delivery of feIL-2, feIFN-gamma and feGM-CSF using magnetofection as a neoadjuvant treatment option for feline fibrosarcomas: a phase-I study. J Vet Med A Physiol Pathol Clin Med 54:599-606

Jordan A, Wust P, Scholz R et al (1996) Cellular uptake of magnetic fluid particles and their effects on human adenocarcinoma cells exposed to $\mathrm{AC}$ magnetic fields in vitro. Int $\mathrm{J}$ Hyperthermia $12: 705-722$

Josephson L, Tung CH, Moore A et al (1999) High-efficiency intracellular magnetic labeling with novel superparamagneticTat peptide conjugates. Bioconjug Chem 10:186-191

Kamau SW, Hassa PO, Steitz B et al (2006) Enhancement of the efficiency of non-viral gene delivery by application of pulsed magnetic field. Nucleic Acids Res 34:e40

Kamau-Chapman SW, Hassa PO, Koch-Schneidemann S et al (2008) Application of pulsed-magnetic field enhances non-viral gene delivery in primary cells from different origins. J Magn Magn Mater 320:1517-1527

Kang YS, Risbud S, Rabolt JF et al (1996) Synthesis and characterization of nanometer-size $\mathrm{Fe}_{3} \mathrm{O}_{4}$ and $\gamma-\mathrm{Fe}_{2} \mathrm{O}_{3}$ particles. Chem Mater 8:2209-2211

Kim JS, Yoon TJ, Yu KN et al (2006) Cellular uptake of magnetic nanoparticle is mediated through energy-dependent endocytosis in A549 cells. J Vet Med Sci 7:321-326

Kreuter J (1994) Nanoparticles. In: Swarbrick J, Boylan JC (eds) Encyclopedia of pharmaceutical technology, vol 10. M. Dekker, New York, pp 165-190

Krötz F, de Wit C, Sohn HY et al (2003a) Magnetofection-a highly efficient tool for antisense oligonucleotide delivery in vitro and in vivo. J Vasc Res 7:700-710

Krötz F, Sohn HY, Gloe T et al (2003b) Magnetofection potentiates gene delivery to cultured endothelial cells. J Vasc Res 40:425434

Leszczynski D (2005) Rapporteur report: cellular, animal and epidemiological studies of the effects of static magnetic fields relevant to human health. Prog Biophys Mol Biol 87:247253

Lu AH, Salabas EL, Schüth F (2007) Magnetic nanoparticles: synthesis, protection, functionalization, and application. Angew Chem Int Ed 46:1222-1244

Luo D, Saltzman WM (2000) Enhancement of transfection by physical concentration of DNA at the cell surface. Nat Biotechnol 18:893-895

Ma YJ, Gu HC (2007) Study on the endocytosis and the internalization mechanism of aminosilane-coated $\mathrm{Fe}_{3} \mathrm{O}_{4}$ nanoparticles in vitro. J Mater Sci Mater Med 18:2145-2149
Makovec D, Kosak A, Znidarsic A (2005) The synthesis of spinelferrite nanoparticles using precipitation in microemulsions for ferrofluid applications. J Magn Magn Mater 289:32-35

Makovec D, Campelj S, Bele M et al (2009) Nanocomposites containing embedded superparamagnetic iron oxide nanoparticles and rhodamine 6G. Colloids Surf A 334:74-79

Maver U, Bele M, Makovec D et al (2009) Incorporation and release of drug into/from superparamagnetic iron oxide nanoparticles. J Magn Magn Mater 321:3187-3192

McBain SC, Yiu HHP, El Haj A et al (2007) Polyethyleneimine functionalized iron oxide nanoparticles as agents for DNA delivery and transfection. J Mater Chem 17:2561-2565

McBain SC, Yiu HHP, Dobson J (2008) Magnetic nanoparticles for gene and drug delivery. Int $\mathrm{J}$ Nanomed 3:169-180

Mirkovic B, Lah Turnsek T, Kos J (2010) Nanotechnology in the treatment of cancer. Zdrav Vestn 79:146-155

Müller RH (1991) Modification of drug carriers. In: Müller RH (ed) Colloidal carriers for controlled drug delivery and targeting: modification, characterization and in vivo distribution. Wissenschaftliche Verlagsgesellschaft, Stuttgart, pp 19-42

Mykhaylyk O, Sánchez-Antequera Y, Vlaskou D et al (2007a) Generation of magnetic nonviral gene transfer agents and magnetofection in vitro. Nat Protoc 2:2391-2411

Mykhaylyk O, Vlaskou D, Tresilwised N et al (2007b) Magnetic nanoparticle formulations for DNA and siRNA delivery. J Magn Magn Mater 311:275-281

Mykhaylyk O, Zelphati O, Hammerschmid E et al (2009) Recent advances in magnetofection and its potential to deliver siRNA in vitro. Methods Mol Biol 487:111-146

Patterson AL (1939) The Scherrer formula for X-ray particle size determination. Phys Rev 56:978-982

Petri-Fink A, Chastellain M, Juillerat-Jeanneret L et al (2005) Development of functionalized superparamagnetic iron oxide nanoparticles for interaction with human cancer cells. Biomaterials 26:2685-2694

Petri-Fink A, Steitz B, Finka A et al (2008) Effect of cell media on polymer coated superparamagnetic iron oxide nanoparticles (SPIONs): colloidal stability, cytotoxicity, and cellular uptake studies. Eur J Pharm Biopharm 68:129-137

Pileni MP (1993) Reverse micelles as microreactors. J Phys Chem 97:6961-6973

Plank C, Scherer F, Schillinger U et al (2003) Magnetofection: enhancing and targeting gene delivery with superparamagnetic nanoparticles and magnetic fields. J Liposome Res 13:29_ 32

Prabha S, Zhou WZ, Panyam J et al (2002) Size-dependency of nanoparticle-mediated gene transfection: studies with fractionated nanoparticles. Int J Pharm 244:105-115

Scherer F, Anton M, Schillinger U et al (2002) Magnetofection: enhancing and targeting gene delivery by magnetic force in vitro and in vivo. Gene Ther 9:102-109

Senyei AE, Widder KJ, Czerlinski C (1978) Magnetic guidance of drug-carrying microspheres. J Appl Phys 498:3578-3583

Sincai M, Ganga D, Ganga M et al (2000) Antitumor effect of magnetite nanoparticles in cat mammary adenocarcinoma. J Magn Magn Mater 293:438-441

Sincai M, Deleanu L, Argherie D et al (2002) The effects of magnetic fluids on blood parameters in dogs. J Magn Magn Mater 252:406-408

Sommerfeld P, Schroeder U, Sabel BA (1998) Sterilization of unloaded polybutylcyanoacrylate nanoparticles. Int $\mathrm{J}$ Pharm 164:113-118

Stöber W, Fink A, Bohn EJ (1968) Controlled growth of monodispersed silica spheres in the micron size range. J Colloid Interface Sci 26:62-69 
Storm G, Belliot SO, Daemen T et al (1995) Surface modification of nanoparticles to oppose uptake by the mononuclear phagocyte system. Adv Drug Deliver Rev 17:31-48

Taira S, Moritake S, Hatanaka T et al (2009) Functionalized magnetic nanoparticles as an in vivo delivery system. Methods Mol Biol 544:571-587

Thassu D, Deleers M, Pathak Y (2007) Nanoparticulate drug delivery systems: an overview. In: Thassu D, Deleers M, Pathak Y (eds) Nanoparticulate drug delivery systems. Informa Healthcare, New York, pp 1-31

Ulman A (1996) Formation and structure of self-assembled monolayers. Chem Rev 96:1533-1554

Vidal-Vidal J, Rivas J, López-Quintela MA (2006) Synthesis of monodisperse maghemite nanoparticles by the microemulsion method. Colloids Surf A 288:44-51

Webb S (1988) In the beginning. In: Webb S (ed) The physics of medical imaging, 3rd edn. Taylor \& Francis, New York, pp 7-19
Widder KJ, Senyei AE, Ranney DF (1979) Magnetically responsive microspheres and other carriers for the biophysical targeting of antitumor agents. Adv Pharmacol Chemother 16:213-271

Wilhelm C, Billotey C, Roger J et al (2003) Intracellular uptake of anionic superparamagnetic nanoparticles as a function of their surface coating. Biomaterials 24:1001-1011

Willard MA, Kurihara LK, Carpenter EE et al (2004) Chemically prepared magnetic nanoparticles. Int Mater Rev 49:125-170

Xiang JJ, Tang JQ, Zhu SG et al (2003) IONP-PLL: a novel non-viral vector for efficient gene delivery. J Gene Med 5:803-817

Yu C, Zhao J, Guo Y et al (2008) A novel method to prepare waterdispersible magnetic nanoparticles and their biomedical applications: magnetic capture probe and specific cellular uptake. J Biomed Mater Res A 87:364-372

Zauner W, Farrow NA, Haines AMR (2001) In vitro uptake of polystyrene microspheres: effect of particle size, cell line and cell density. J Control Release 71:39-51 